\title{
Reversal effect and mechanism of Ginkgo biloba exocarp extracts in multidrug resistance of mice S180 tumor cells
}

\author{
BI-YUAN HU, YUN-HAO GU, CHEN-JIE CAO, JUN WANG, DONG-DONG HAN, \\ YING-CHAO TANG, HUA-SHENG CHEN and AIHUA XU
}

\begin{abstract}
Department of Pharmacology, Medical College of Yangzhou University, Jiangsu Co-Innovation Center for Prevention and Control of Important Animal Infectious Diseases and Zoonoses, Yangzhou, Jiangsu 225001, P.R. China
\end{abstract}

Received February 12, 2015; Accepted June 22, 2016

DOI: $10.3892 /$ etm.2016.3589

\begin{abstract}
The aim of the present study was to investigate the reversal effect and its related mechanism of Ginkgo biloba exocarp extracts (GBEEs) in obtained multidrug resistance (MDR) of mice S180 tumor cells in vitro and in vivo. In order to simulate the clinical PFC [cis-dichlorodiamineplatinum, cisplatin (DDP) + fluorouracil (FU), FU+cyclophosphamide and cyclophosphamide] scheme, a gradually increasing dose was administered in a phased induction in order to induce $\mathrm{S} 180$ cells in vivo and to make them obtain multidrug resistance. The results in vitro demonstrated that GBEE could significantly increase the $\mathrm{IC}_{50}$ of DDP on S180 MDR cells, increase the accumulation of Adriamycin (ADR) and rhodamine 123 (Rho 123), and reduce the efflux of Rho 123 of S180 MDR cells. The results from the in vivo treatment with a combination of GBEE and DDP to S180 MDR ascites tumor in mice demonstrated that each dose of GBEE could effectively reverse the drug-resistance of S180 MDR cells to DDP in order to extend the survival time of mice with ascite tumors and inhibit tumor growth in solid tumor mice. In addition, GBEE effectively inhibited the expression of MDR-1 mRNA and multidrug resistance-associated protein-1 mRNA in S180 MDR cells of ascites tumor in mice and improved the expression levels of cytokines, including interleukin (IL)-3, IL-18 and interferon- $\gamma$ in the blood serum of S180 MDR tumor-bearing mice. The present study showed that the mechanism of GBEE reversal of MDR may be associated with the inhibition of the functional activity of P-glycoprotein, the downregulation of drug resistance related gene expression of S180 MDR cells and the
\end{abstract}

Correspondence to: Professor Aihua $\mathrm{Xu}$, Department of Pharmacology, Medical College of Yangzhou University, Jiangsu Co-Innovation Center for Prevention and Control of Important Animal Infectious Diseases and Zoonoses, 11 Huaihai Road, Yangzhou, Jiangsu 225001, P.R. China

E-mail: ahxu@yzu.edu.cn

Key words: Ginkgo biloba exocarp extracts, multidrug resistance, p-glycoprotein, drug-resistant genes, cytokines improvement of the production of related serum cytokines of S180 MDR tumor mice.

\section{Introduction}

Multidrug resistance (MDR) refers to the tumor cells having a resistance to a type of antitumor medicine, while also having a cross resistance to the chemical structure and mechanism of action of other completely different types of antitumor drugs (1), which is a predominant cause in the failure of chemotherapy. MDR can result in the overexpression of transporter proteins, including P-glycoprotein (P-gp), multidrug resistance-associated protein (MRP), lipoprotein receptor-related protein (LRP) and others proteins (2-4), which belong to the ATP-binding cassette (ABC) transporters. The ABC transporters are a superfamily of transmembrane proteins that transport a wide variety of substrates across the extracellular and intracellular membranes (5). Furthermore, MDR is also closely linked to the tumor microenvironment, especially the immune system (6). However, cytokines that are produced by the immune system have been studied by more and more people $(7,8)$.

Cytokines are small proteins or small molecular peptides, such as interleukin 3 (IL-3) mainly secreted by T lymphocytes (9), interferon- $\gamma($ IFN- $\gamma$ ) secreted by $\mathrm{T}$ lymphocytes and natural killer cells (10) and tumor necrosis factor- $\alpha$ (TNF- $\alpha$ ) secreted by macrophages (11). They can transmit information between the cells and serve an important role in immune regulation and anti-tumor effects amongst others (12). The immune cells that secrete cytokines can recognize the abnormaly high expression of P-gp, MDR-1 and MRP-1 in MDR cells and react with them. Proteins such as P-gp and MRP, which offer chemoresistance, were overexpressed in tumor cells. Furthermore, their growth status is different from that of normal cells. May be when resistant proteins increase in tumor cells, some immune cells can recognize and react to them, for example by secreting cytokines, in order to reverse drug resistance (13-15). This part of the study has attracted increasingly more attention from scholars and thus revealing the mechanism will help to solve the effective treatment of tumor MDR.

It was recently revealed that two compounds called verapamil (VER) (16) and cyclosporin A (CsA) (17) amongst 
other chemical reversal agents were capable of improving the sensitivity of tumor cells to a certain extent, which can improve the clinical effect of chemotherapy when combined with the use of anti-tumor chemotherapeutic drugs. However, CsA has immunosuppressive properties and can cause renal toxicity which restricts its application. VER, a calcium antagonist, has a relatively small adverse reaction, but due to the lack of its antitumor effects doctors rarely use it in chemotherapy regimens. Therefore it is important to identify novel and effective clinical reversal agents.

Experimental studies have demonstrated that GBEE has anti-tumor, anti-metastasic and synergistic attenuated effects that could improve the body's immune function in different conditions (18-21). Clinical studies demonstrated that GBEE capsules could shrink gastric cancer tumors and improved the quality of life of many kinds of cancer patients. Furthermore it has been used for many years in the hospital and no adverse reactions have been reported (22). In addition, the possibility of using GBEE to reverse multidrug resistance of tumors and its clinical application have not yet been reported.

In the present study, in order to simulate the commonly clinical PFC [(cis-dichlorodiamineplatinum, cisplatin (DDP)+fluorouracil (FU), FU+cyclophosphamide (CPA)] scheme, a gradually increasing dose in a phased induction was used in vivo to induce S180 cells and make them have MDR. S180 MDR ascites tumor mouse models were established in order to study the reversal effects and mechanism of GBEE in MDR of S180 mice tumor cells in vitro and in vivo.

\section{Materials and methods}

Ginkgo biloba exocarp extracts (GBEE) preparation. GBEEs is a Chinese traditional medicine Ginkgo fruit that was collected in October 2013 in Taixing, China. GBEE was prepared by water extraction and alcohol precipitation (23). Infrared spectroscopy qualitative analysis shows that it contains protein polysaccharide, the total content being $66.4 \%$, which was identified using the phenol-sulfuric acid and Coomassie brilliant blue methods. It was extracted from the exopleura of the Chinese traditional medicine Ginkgo biloba (identified by Yin Meng, a senior pharmacist, at the Yangzhou Institute for Drug Control, Yangzhou, China).

Cell culture and establishment of an S180 MDR cell line in mice. Mouse S180 cell line (Chinese Academy of Sciences, Institute of Cell Biology, Shanghai, China) was inoculated in the abdominal cavity of ICR mice (Comparative Medicine Center of Yangzhou University, Yangzhou, China) after the in vitro amplification was done once every seven to eight days. The S180 cells of ascites tumor in mice were extracted under aseptic conditions and seeded at an initial concentration of $1 \times 10^{6}$ cells $/ \mathrm{ml}$. A total of $0.2 \mathrm{ml}$ of cell suspension was injected into the abdominal cavity of mice from the right lower abdomen. After $24 \mathrm{~h}$, in order to simulate the commonly clinical PFC scheme, DDP (Jiangsu Howson Pharmaceutical Co., Ltd, Jiangsu, China) was injected intraperitoneally (ip), once a week; FU (Tianjin Jin Yao Amino Acid Co., Ltd, Tianjin, China), intragastrically (ig) once a day and CPA (Jiangsu Hengrui Medicine Co., Ltd,
Jiangsu, China), ig once a day. The gradually increasing dose at different stages was used to induce S180 cells and make them obtain MDR, which was named as the S180 MDR cell line $(24,25)$. At the first stage $3.0 \mathrm{mg} / \mathrm{kg}$ $\mathrm{DDP}+3.0 \mathrm{mg} / \mathrm{kg} \mathrm{FU}+3.0 \mathrm{mg} / \mathrm{kg} \mathrm{CPA}$ was given and the induction time was two generations; At the second stage $4.0 \mathrm{mg} / \mathrm{kg} \mathrm{DDP}+6.0 \mathrm{mg} / \mathrm{kg} \mathrm{FU}+6.0 \mathrm{mg} / \mathrm{kg} \mathrm{CPA}$ and an induction time of two generations was given; Finally, at the third stage $5.0 \mathrm{mg} / \mathrm{kg}$ DDP $+12.0 \mathrm{mg} / \mathrm{kg} \mathrm{FU}+12.0 \mathrm{mg} / \mathrm{kg} \mathrm{CPA}$ and an induction time of two generations was given. This study was approved by the Ethics committee of the Medical College of Yangzhou University.

Reverse index determined by the MTT assay. The S180MDR cells were seeded in RPMI 1640 medium (Gibco-BRL, Invitrogen Life Technologies, Carlsbad, CA, USA) supplemented with $10 \%$ heat-inactivated new born bovine serum (Hangzhou Sijiqing Biological Engineering Materials Co., Ltd, Hangzhou, China) at an initial concentration of $1 \times 10^{5}$ cells/ml with $100 \mu \mathrm{l} /$ well in 96 -well culture plates. A blank and a control group, various concentrations of DDP groups, various concentrations of GBEE + DDP groups, a VER group (Xuzhou Pharmaceutical Co., Ltd, Xuzhou, China) and a VER + DDP group were all set up. A cell inhibitory rate less than $10 \%$ was named as nontoxic dose, and the nontoxic dose of GBEE to S180 MDR cells was $15 \mu \mathrm{g} / \mathrm{ml}$ which was obtained by preliminary experiments. Therefore, GBEE concentrations of $7.5,15$ and $30 \mu \mathrm{g} / \mathrm{ml}$ were selected as the reversal doses in vitro. Following administration of the compound the culture plate was placed in $5 \% \mathrm{CO}_{2}$ in a $37^{\circ} \mathrm{C}$ incubator (Thermo Fisher Scientific, Inc., Waltham, MA, USA) for $44 \mathrm{~h}$. After each well had absorbed the supernatant $(100 \mu \mathrm{l}), 10 \mu \mathrm{l}$ MTT solution was added $(0.5 \mathrm{mg} / \mathrm{ml}$; Sigma-Aldrich, St. Louis, MO, USA) for $4 \mathrm{~h}$ before the end of incubation. Next, $100 \mu \mathrm{l}$ acidified isopropanol was added to each well and quickly mixed in the solution. The absorbance at $570 \mathrm{~nm}(26,27)$ was measured using a Enzyme-linked immune detector (BioTek Instruments, Inc., Winooski, VT, USA). The half maximal inhibitory concentration $\left(\mathrm{IC}_{50}\right)$ and the resistance index (RI) were calculated.

Flow cytometry for accumulation of ADR in cells. Parent S180 cells and S180 MDR cells were seeded in RPMI 1640 complete medium containing $5.0 \mu \mathrm{g} / \mathrm{ml}$ Adriamycin (ADR; Zhejiang Haizheng Pharmaceutical Co., Ltd, Zhejiang, China) at an concentration of $1 \times 10^{6}$ cells $/ \mathrm{ml}$ in $24-w e l l$ culture plates. The parent S180 was set as the cell blank group and S180 MDR cells as the control group. Furthemore, other groups were those with GBEE at 7.5, 25 and $30 \mu \mathrm{g} / \mathrm{ml}$ concentrations and the VER group with a concentration of $5.0 \mu \mathrm{g} / \mathrm{ml}$. Finally, the final volume of each well was $2.0 \mathrm{ml}$ and three parallel samples of each group were set up. Following $3 \mathrm{~h}$ of incubation at $5 \% \mathrm{CO}_{2}$ and $37^{\circ} \mathrm{C}$, the cells were washed three times with ice-cold phosphate-buffered saline (PBS). Finally, the cells were resuspended in $1.0 \mathrm{ml}$ ice-cold PBS and uniformly mixed. The mean fluorescence intensity (MFI) of ADR in 10,000 cells was detected by flow cytometry (BD FACSCalibur flowcytometer, BD Biosciences Franklin Lakes, NJ, USA), and the excitation and emission wavelengths of ADR were 488 and $575 \mathrm{~nm}$, respectively. 
$P$-gp activity study. Activity experiments were performed by measuring the accumulation and efflux of Rhodamine 123 (Rho 123, Sigma-Aldrich), a well-known P-gp substrate, which is inversely proportional to the P-gp activity $(28,29)$. When measuring the accumulation of Rho 123, parent S180 cells and S180 MDR cells were seeded in RPMI 1640 complete medium containing $2.0 \mu \mathrm{g} / \mathrm{ml}$ Rho 123 at an concentration of $1 \times 10^{6}$ cells $/ \mathrm{ml}$ in 24 -well culture plates. The experiment groups were the same as above. The final volume of each well was $2.0 \mathrm{ml}$ and there were a total of three parallel samples of each group. Following $3 \mathrm{~h}$ of incubation at $5 \% \mathrm{CO}_{2}$ and $37^{\circ} \mathrm{C}$, the cells were washed three times with ice-cold PBS. Finally, the cells were resuspended in $1.0 \mathrm{ml}$ ice-cold PBS and uniformly mixed. The MFI of Rho 123 in 10,000 cells was detected by flow cytometry.

When measuring the efflux of Rho 123, the early steps used involved seeding parent S180 and MDR cells in RPMI 1640 complete medium containing $2.0 \mu \mathrm{g} / \mathrm{ml}$ Rho 123 at a concentration of $1 \times 10^{6}$ cells $/ \mathrm{ml}$ and in $24-w e l l$ culture plates. The final volume was $2.0 \mathrm{ml}$ and the culture was incubated at $37^{\circ} \mathrm{C}$ and $5 \% \mathrm{CO}_{2}$ in a constant temperature incubator. When measuring the efflux of Rho 123, the early steps were the same as those obtained when measuring the accumulation of Rho 123. Following $2 \mathrm{~h}$ of incubation with $5 \% \mathrm{CO}_{2}$ at $37^{\circ} \mathrm{C}$, the cells were washed three times with ice-cold phosphate-buffered saline (PBS), then resuspended in RPMI 1640 complete medium without Rho 123 and again incubated for $1 \mathrm{~h}$. Finally, the cells were resuspended in $1.0 \mathrm{ml}$ ice-cold PBS and were uniformly mixed after being washed three times with ice-cold PBS. At last, the MFI of Rho 123 in 10,000 cells was detected by flow cytometry. The excitation and emission wavelengths of Rho 123 were 488 and $530 \mathrm{~nm}$, respectively.

Determination of life-prolonging rate in vivo. The S180 MDR cells of ascites tumor in mice were extracted under aseptic conditions and seeded at an initial concentration of $1 \times 10^{6}$ cells $/ \mathrm{ml}$. A $0.2 \mathrm{ml}$ cell suspension was injected into the abdominal cavity of mice from the right lower abdomen to establish the model of S180 MDR ascites tumor in mice. After $24 \mathrm{~h}$, the mice were randomly divided into a blank and a control group, $3.0 \mathrm{mg} / \mathrm{kg}$ cis-dichlorodiamineplatinum (DDP), 12.5, 25 and $50 \mathrm{mg} / \mathrm{kg}$ GBEE medicine concentration groups, $12.5,25$ and $50 \mathrm{mg} / \mathrm{kg} \mathrm{GBEE}+3.0 \mathrm{mg} / \mathrm{kg}$ DDP combination groups, $15 \mathrm{mg} / \mathrm{kg}$ VER, $15 \mathrm{mg} / \mathrm{kg}$ VER $+3.0 \mathrm{mg} / \mathrm{kg}$ DDP combination group, and there were 10 mice in each group. DDP was administered ip every two days, and GBEE and VER were administered intragastrically once daily. The tumor inhibitory rate less than $10 \%$ was defined as the nontoxic dose, and the nontoxic dose of GBEE to S180 MDR ascites tumor in mice was $25 \mathrm{mg} / \mathrm{kg}$, which obtained by preliminary experiments. Therefore GBEE at doses of 12.5, 25 and $50 \mathrm{mg} / \mathrm{kg}$ were selected as the reversal dose in vivo. After administering the drugs for one week, the mice were normally fed until they had a natural death. The survival of tumor-bearing mice and the survival time of the mice were observed daily. The maximum survival time recorded was 60 days, where mice living for more than 60 days was recorded as $60 \mathrm{~d}(30)$. At that point the life-prolonging rate of mice was calculated.
Determination of tumor inhibitory rate in vivo. The cells in S180 MDR ascites tumor in mice were obtained under aseptic conditions and seeded at an initial concentration of $1 \times 10^{6}$ cells $/ \mathrm{ml}$. A $0.2 \mathrm{ml}$ cell suspension was injected into the right forelimb armpit in mice in order to establish the model of S180 MDR transplantable solid tumor mice. The experiment groups and the method of drug delivery were the same as above. After stopping the drug delivery for 7 days, all the mice were sacrificed, the tumors were excised and weighed and the tumor inhibition rate was weighted.

Expression analysis of MDR-1 $m R N A$ and MRP-1 $m R N A$ by quantitative polymerase chain reaction ( $q P C R)$. The total RNA was extracted from the S180 MDR ascites tumor cells from alive mice of the different groups (treated with various concentrations of GBEE, VER or combinations of DDP) using TRIzol Reagent (Sangon Biotech, Co., Ltd, Shanghai, China) according to the manufacturer's instructions. The supernatant was removed by centrifugation after each group of cells were treated by the drugs. $1 \mathrm{ml}$ TRIzol was added to each group and the solution was pipetted at room temperature for $5 \mathrm{~min}$ several times. In total $0.2 \mathrm{ml}$ chloroform (Chinese Medicine Group Chemical Reagent Co., Ltd.) was added, and the reaction was vortexed for $15 \mathrm{sec}$ at room temperature for $3 \mathrm{~min}$. The solution was centrifuged at $9,180 \mathrm{x} \mathrm{g}$ for $15 \mathrm{~min}$ at $4^{\circ} \mathrm{C}$ and the upper colorless aqueous phase was carefully removed $(\sim 600 \mu \mathrm{l})$ and transferred to an RNase-free $1.5 \mathrm{ml}$ Eppendorf tube. An equal volume of isopropanol (Chinese Medicine Group Chemical Reagent Co., Ltd.) was added, then mixed and placed at room temperature for 20 mins. The solution was then centrifuged at $9,180 \mathrm{xg}$ for $10 \mathrm{~min}$ at $4^{\circ} \mathrm{C}$ and the supernatant was removed. $1 \mathrm{ml}$ of $75 \%$ ethanol (National Pharmaceutical Group Chemical Reagent Co., Ltd.) was added and the precipitate was pelleted by centrifugation at $2,683 \times \mathrm{g}$ for $3 \mathrm{~min}, 4^{\circ} \mathrm{C}$ and the supernatant was carefully separated. The pellet was placed at room temperature to dry for 2-3 min and $30 \mu \mathrm{l}$ RNase-Free $\mathrm{ddH}_{2} \mathrm{O}$ was added and stirred for several times until the RNA was fully dissolved. $2 \mu 1$ were used in order to determine the OD260/OD280 ratio and the RNA concentration in the final solution was determined by UV spectrophotometry. The remaining samples were kept at $-80^{\circ} \mathrm{C}$.

Thereafter, $2.0 \mu \mathrm{g}$ total RNA was used to perform first-strand cDNA synthesis (Takara Biotechnology, Co., Ltd., Dalian, China) and SYBR Green fluorescence qPCR analysis (Takara Biotechnology, Co. Ltd.) was performed using an Applied Biosystems 7500 real time-PCR analyzer (Carlsbad, CA, USA). The primer sequences were as follows: Forward, 5'-ATGACACCCCTGAAATCCA-3' and reverse, 5'-CGCTCCTGTGGTGTTTTTA-3' for the MDR-1 gene, and the length of the PCR product was $215 \mathrm{bp}$. The second primer sequence was as follows: Forward, 5'-CCTACT ACCCCAGCATTGT-3' and reverse, 5'-TATTCCTTCAGT CTCTCCAC-3' for the MRP-1 gene, and the length of the PCR product was $238 \mathrm{bp}$. The third primer sequence was as follows: Forward, 5'-CTTAGCACCCCTGGCCAAG-3' and reverse, 5'-GATGTTCTGGAGAGCCCCG-3' for the housekeeping gene GAPDH, the length of the PCR product was 450 bp. The above primers were synthesized by Sangon Biotech, Co., Ltd. The following reagents were used in 
Table I. Effect of GBEE on reversing resistance in S180 MDR cells.

\begin{tabular}{|c|c|c|c|c|}
\hline \multirow[b]{2}{*}{ Groups } & \multicolumn{2}{|c|}{$\mathrm{IC}_{50}(\mu \mathrm{g} / \mathrm{ml})$} & \multirow[b]{2}{*}{$\mathrm{RF}$} & \multirow[b]{2}{*}{ RI } \\
\hline & $\mathrm{S} 180$ & S180 MDR & & \\
\hline $\mathrm{DDP}(\mu \mathrm{g} / \mathrm{ml})$ & $0.068 \pm 0.018$ & $0.724 \pm 0.071$ & 10.90 & \\
\hline \multicolumn{5}{|c|}{ DDP+GBEE $(\mu \mathrm{g} / \mathrm{ml})$} \\
\hline 30 & $0.048 \pm 0.013$ & $0.085 \pm 0.009$ & 1.77 & 8.73 \\
\hline 15 & $0.054 \pm 0.027$ & $0.063 \pm 0.017$ & 1.17 & 11.49 \\
\hline 7.5 & $0.075 \pm 0.005$ & $0.073 \pm 0.021$ & 0.97 & 10.16 \\
\hline \multicolumn{5}{|c|}{ DDP+VER $(\mu \mathrm{g} / \mathrm{ml})$} \\
\hline 5 & $0.065 \pm 0.014$ & $0.098 \pm 0.045$ & 1.51 & 7.39 \\
\hline
\end{tabular}

the reverse transcription reaction: $2 \mu 15 \mathrm{X}$ Primescript RT master mix, $1 \mu \mathrm{g}$ total RNA and RNase-free $\mathrm{ddH}_{2} \mathrm{O}$ up to $10 \mu 1$. SYBR Premix Taq II DNA polymerase (Takara Biotechnology, Co., Ltd.) was used. The reverse transcriptase reaction conditions were as follows: $37^{\circ} \mathrm{C}$ for $15 \mathrm{~min}, 85^{\circ} \mathrm{C}$ for $5 \mathrm{sec}$ and a cooling step at $4^{\circ} \mathrm{C}$. qPCR was conducted using the following conditions: $95^{\circ} \mathrm{C}$ for $30 \mathrm{sec}$ followed by 40 cycles of $95^{\circ} \mathrm{C}$ for $5 \mathrm{sec}$ and $60^{\circ} \mathrm{C}$ for $34 \mathrm{sec}$, and a dissociation curve analysis of the amplification products was performed at the end of each PCR reaction to confirm that only one product was amplified and detected. The relative mRNA levels were calculated by the $2^{-\Delta \Delta \mathrm{Cq}}$ method (31), and the experiment was repeated three times. Furthermore, a negative control was used that consisted of mice inoculated with parental and drug resistant cells, which were fed under the same conditions as the other groups. However, the same volume of normal saline was administered instead of drugs.

Determination of cytokines serum levels. The serum was obtained from S180 MDR tumor-bearing mice and the IL-3, IL-18 and IFN- $\gamma$ levels were measured by a double antibody sandwich ELISA method (Bio-Swamp, Chinese Bang Yi Trading Co., Ltd, Shanghai, China). All the assays were performed according to the manufacturer's instructions.

Statistical analysis. Data were expressed as the mean \pm standard deviation. Statistical significance was assessed using one-way analysis of variance with SPSS 16.0 software (SPSS Inc., Chicago, IL, USA) where $\mathrm{P}<0.05$ was considered to indicate a statistically significant difference.

\section{Results}

Effect of GBEE on reversing resistance activity in S180 MDR cells. The $\mathrm{IC}_{50}$ of DDP on parent S180 cells was $0.068 \mu \mathrm{g} / \mathrm{ml}$, while the $\mathrm{IC}_{50}$ of DDP on S180 MDR cells was $0.724 \mu \mathrm{g} / \mathrm{ml}$. The RI of S180 MDR cells after DDP was 10.90 . Following treatment of the cells with DDP + GBEE at 7.5, 15 and $30 \mu \mathrm{g} / \mathrm{ml}$ and VER at $5.0 \mu \mathrm{g} / \mathrm{ml}$, respectively, there was a significant decrease of the $\mathrm{IC}_{50}$ of DDP on S180 MDR cells (Table I). The results indicated that GBEE could effectively reverse the resistance of S180 MDR cells to DDP.

GBEE increased intracellular accumulation of ADR. The capability of GBEE to affect the accumulation of ADR within S180 MDR cells was examined by flow cytometry (Fig. 1). The accumulation of ADR within parent S180 and S180 MDR cells was 250.82 \pm 5.86 and 113.37 \pm 7.26 (mean fluorescence intensity), respectively. After adding GBEE at $7.5,15$ and $30 \mu \mathrm{g} / \mathrm{ml}$ concentrations and VER at $5.0 \mu \mathrm{g} / \mathrm{ml}$, the residual amount of ADR within S180 MDR cells increased to $204.38 \pm 4.89,211.89 \pm 11.21,188.92 \pm 3.57,208.52 \pm 8.22$, respectively. In comparison with the S180 MDR control group the differences were significant $(\mathrm{P}<0.001)$.

GBEE improved functional activity of P-gp. The effect of GBEE on the accumulation and efflux of Rho 123 in S180 and S180 MDR cells was determined by flow cytometry. As shown in Fig. 2, compared with the parent cells, the accumulation of Rho 123 in S180 MDR cells was significantly reduced, and the efflux of Rho 123 was markedly increased $(\mathrm{P}<0.05)$. However, GBEE and VER inhibited the activity of P-gp. Fig. 2 demonstrated that GBEE markedly increased the accumulation of Rho 123 and induced the efflux of Rho 123 in S180 MDR cells. GBEE at 15 and $7.5 \mu \mathrm{g} / \mathrm{ml}$ were more effective.

GBEE enhanced the efficacy of DDP in vivo to prolong the survival time of $S 180 \mathrm{MDR}$ cell of ascites tumor in mice. An established S180 MDR cell ascites tumor mouse model was used to evaluate the efficacy of GBEE to enhance the sensitivity of DDP in S180 MDR cells and to prolong the survival time in vivo. There was no significant difference in the survival time between animals treated with DDP $3.0 \mathrm{mg} / \mathrm{kg}$ and GBEE 12.5, 25 and $50 \mathrm{mg} / \mathrm{kg}$. However, the combination of GBEE and DDP could effectively reverse the drug resistance of S180 MDR ascites tumor cells and prolong the survival time of mice. The life-prolonging rate of the 
A

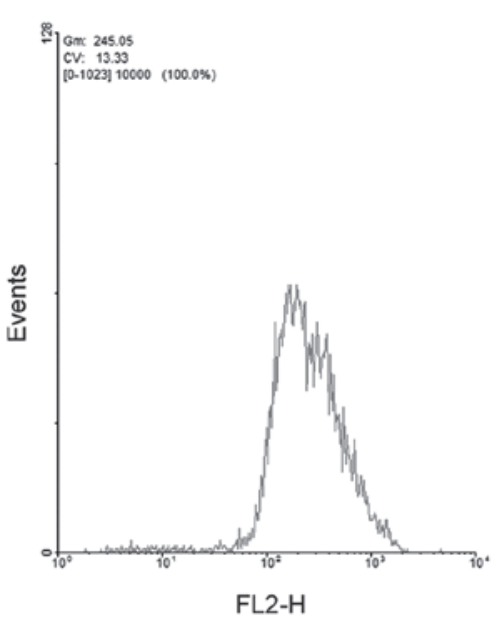

D

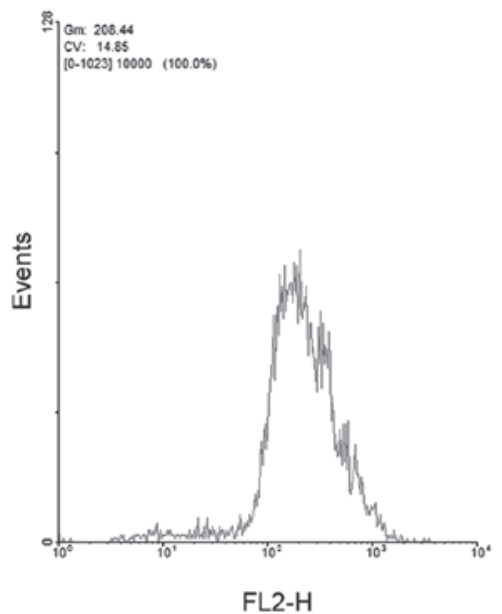

B
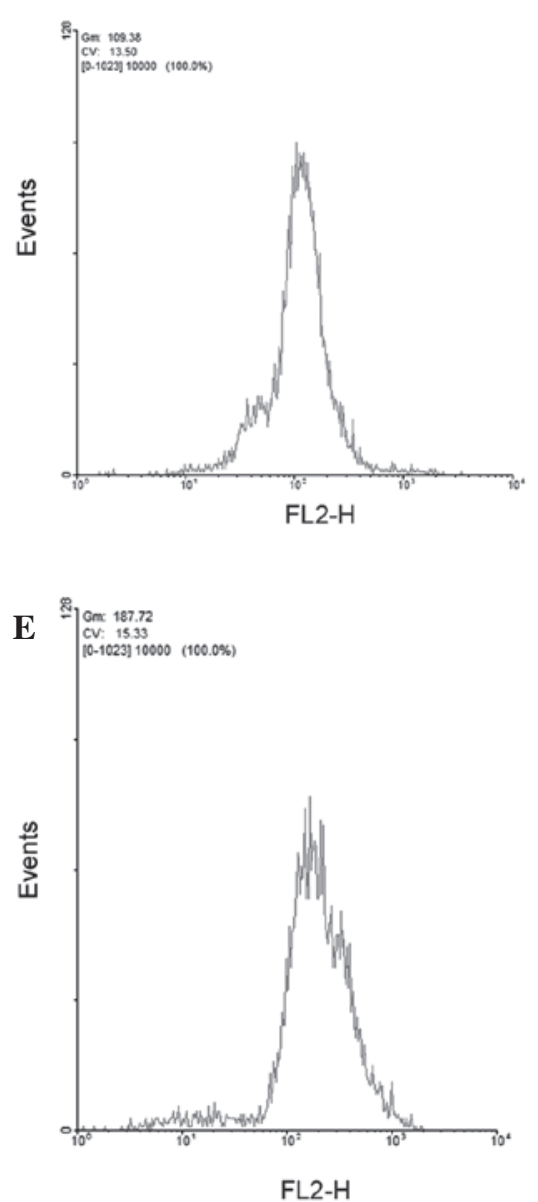

C
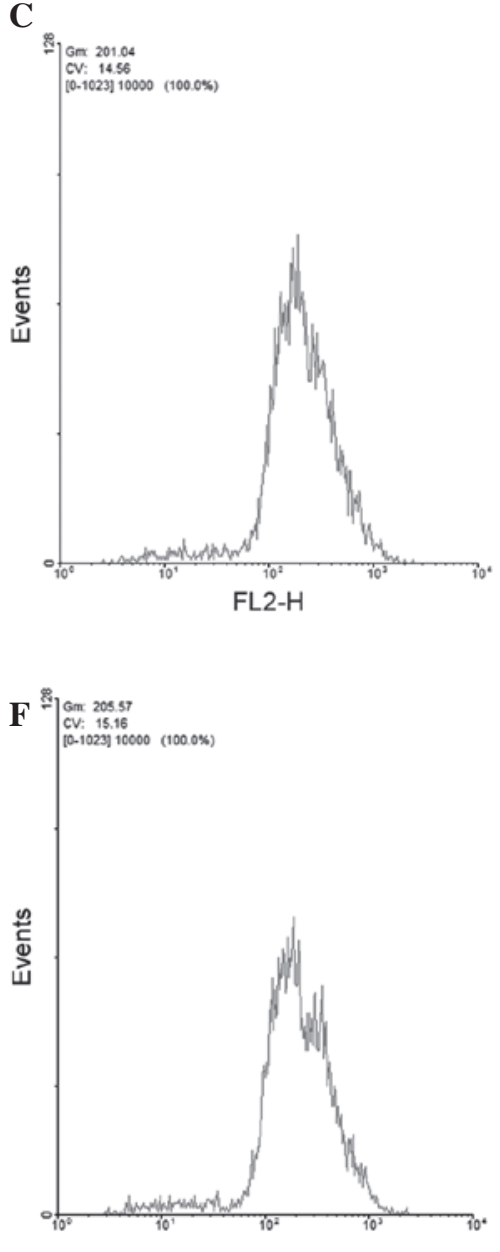

FL2-H

Figure 1. Effects of GBEE on the accumulation of ADR in S180 MDR cells. (A) Parent S180 an (B) S180 MDR cells treated with $5.0 \mu \mathrm{g} / \mathrm{ml} \mathrm{ADR}$ for $3 \mathrm{~h}$. (C) S180 MDR cells treated with ADR $5.0 \mu \mathrm{g} / \mathrm{ml}+$ GBEE 7.5, (D) 15 and (E) $30 \mu \mathrm{g} / \mathrm{ml}$ for $3 \mathrm{~h}$. (F) S180 MDR cells treated with $5.0 \mu \mathrm{g} / \mathrm{ml} \mathrm{ADR} \mathrm{+} 5 \mu \mathrm{g} / \mathrm{ml} \mathrm{VER}$ for 3 h. GBEE, Ginkgo biloba exocarp extracts; ADR, Adriamycin; VER, verapamil; S180 MDR, mouse S180 sarcoma cell line with chemotherapeutic drug resistance; Gm shows the average fluorescence intensity; FL2-H and CV show the channel name and voltage for the absorption process.

DDP group was $7.89 \%$, while the life-prolonging rate after the combined treatment was $25.00,39.58,29.17$ and $33.59 \%$, respectively, which showed a significant difference compared with animals treated with DDP and GBEE alone $(\mathrm{P}<0.05$; Table II).

GBEE enhanced the efficacy of DDP in vivo to inhibit tumor growth in S180 MDR transplantable solid tumor mice. The efficacy of GBEE to reverse the sensitivity of DDP in S180 MDR cells and to inhibit tumor growth in vivo was evaluated by a S180 MDR transplantable solid tumor mouse model. GBEE at 12.5, 25 and $50 \mathrm{mg} / \mathrm{kg}$ and DDP $3.0 \mathrm{mg} / \mathrm{kg}$ alone did not show a significant tumor inhibitory effect on S180 MDR transplantable solid tumor growth. However, the combination of DDP $3.0 \mathrm{mg} / \mathrm{kg}$ and GBEE 12.5, 25 and $50 \mathrm{mg} / \mathrm{kg}$ markedly decreased the tumor mass, and the tumor inhibitory rate of DDP was increased from 19.92 to $61.60,65.43$ and $46.09 \%$, respectively, with a significant differences $(\mathrm{P}<0.001$; Table III). Meanwhile, the tumor inhibitory rate of DDP $3.0 \mathrm{mg} / \mathrm{kg}+$ VER $15 \mathrm{mg} / \mathrm{kg}$ was $60.76 \%$. The effect observed was equal to that of the combination of DDP $3.0 \mathrm{mg} / \mathrm{kg}$ and GBEE 12.5 and $25 \mathrm{mg} / \mathrm{kg}$, and the results indicated that
GBEE could effectively reverse the sensitivity of DDP in S180 MDR cells and enhance the tumor inhibitory effect.

GBEE induced the expression level of MDR-1 $m R N A$, MRP-1 mRNA in S180 MDR ascites tumor mouse cells in vivo. In order to determine whether GBEE mediated reversal effects on $\mathrm{ABC}$ transporters in vivo, the cellular RNAs were isolated from S180 MDR ascites tumor mouse cells and the MDR-1 mRNA and MRP-1 mRNA expression was analyzed by qPCR. As shown in Fig. 3A and B, two mRNA expression levels of S180 MDR cells of the control group were $3.448,3.906$ times higher than parent S180 cells from the blank group. Nevertheless, the two gene expression levels of GBEE $12.5,25$ and $50 \mathrm{mg} / \mathrm{kg}$ alone and its combinational groups were decreased. Furthermore, there were significant changes compared with control and DDP $3.0 \mathrm{mg} / \mathrm{kg}$ groups. These results indicated that GBEE could overcome the DDP resistance of S180 MDR cells of ascites tumor mice via the downregulation of MDR-1 and MRP-1. As shown in Fig. 3C and D, the melting curve of the MDR-1 mRNA, MRP-1 mRNA and GAPDH amplification products in cells of different groups had a single peak and no other 
Table II. The life-prolonging rate by a combination of GBEE and DDP in a S180 MDR ascites tumor mouse model.

\begin{tabular}{lcc}
\hline Group & $\begin{array}{c}\text { Surviving } \\
\text { time (day) }\end{array}$ & $\begin{array}{c}\text { Life-prolonging } \\
\text { rate (\%) }\end{array}$ \\
\hline Blank & & $12.88 \pm 1.17$ \\
Control & & $12.00 \pm 1.99$ \\
DDP & $12.81 \pm 1.04$ & 7.89 \\
GBEE $(\mathrm{mg} / \mathrm{kg})$ & $12.46 \pm 1.79$ & 3.87 \\
50 & $12.47 \pm 1.26$ & 3.92 \\
25 & $12.21 \pm 0.53$ & 1.74 \\
12.5 & & \\
GBEE+DDP $(\mathrm{mg} / \mathrm{kg})$ & $15.00 \pm 1.55^{\mathrm{a}}$ & 25.00 \\
$50+3$ & $16.75 \pm 1.81^{\mathrm{b}}$ & 39.58 \\
$25+3$ & $15.50 \pm 0.86^{\mathrm{a}}$ & 29.17 \\
$12.5+3$ & $12.82 \pm 2.20$ & 6.85 \\
VER & $16.03 \pm 0.92^{\mathrm{b}}$ & 33.59 \\
VER+DDP &
\end{tabular}

Data are presented as the mean \pm standard deviation for each group of ten mice. The blank group is the parent cell without any treatment; The control group consists of the S180 MDR cells without any treatment. DDP $3 \mathrm{mg} / \mathrm{kg}$ was administered intraperitoneally every two days, GBEE 12 . $5,25,50 \mathrm{mg} / \mathrm{kg}$ and VER $15 \mathrm{mg} / \mathrm{kg}$ were administered intragastrically once daily. ${ }^{\mathrm{a}} \mathrm{P}<0.05$ and ${ }^{\mathrm{b}} \mathrm{P}<0.01$ vs. DDP; GBEE, Ginkgo biloba exocarp extracts; DDP, cis-dichlorodiamineplatinum; VER, verapamil; S180 MDR, mice S180 sarcoma cell line with chemotherapeutic drug resistance.

impurity peak. This showed that the fluorescent signals from SYBR Green were all PCR amplification products without any primer dimer and non-specific products.

GBEE promoted cytokine serum levels of S180 MDR tumor-bearing mice. The effect of GBEE on the IL-3, IL-18 and IFN- $\gamma$ serum levels of S180 MDR tumor-bearing mice was determined by ELISA. The levels of each cytokine are shown in Fig. 4. It was observed that the serum levels of three cytokines in the blank group mice were significantly higher than the control. The reason for this may be that MDR inhibited the production of cytokines. Compared with the blank and control groups respectively, GBEE 12.5, 25 and $50 \mathrm{mg} / \mathrm{kg}$ alone and its combinational groups could significantly enhance the serum levels of IL-3, IL-18 and IFN- $\gamma$ in S180 MDR tumor-bearing mice. The levels of these three cytokines in DDP $3 \mathrm{mg} / \mathrm{kg}$ group were $1,625 \pm 70.71$, $33.27 \pm 0.47$ and $124.50 \pm 19.80 \mathrm{pg} / \mathrm{ml}$. Under the effect of GBEE $25 \mathrm{mg} / \mathrm{kg}$, the levels increased to $3,079 \pm 262.34$, $121.94 \pm 20.27$ and $409.67 \pm 8.73 \mathrm{pg} / \mathrm{ml}$, respectively.

\section{Discussion}

Currently researchers in China and around the world have focused on finding highly-efficient and harmless MDR reversal agents (with antitumor properties) from traditional Chinese Medicine or natural plant medicine. According to
$\mathbf{A}$

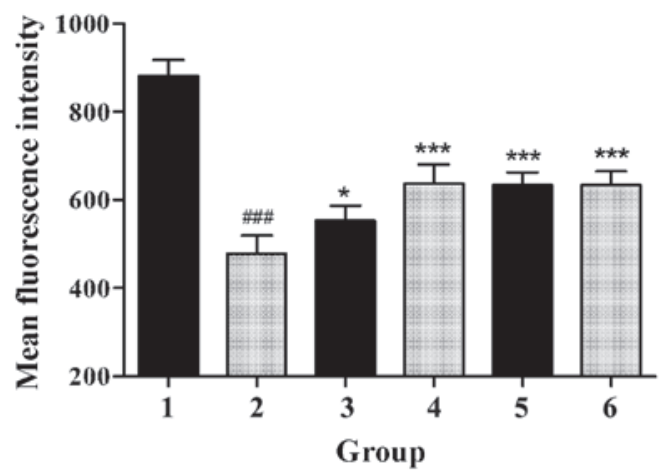

B

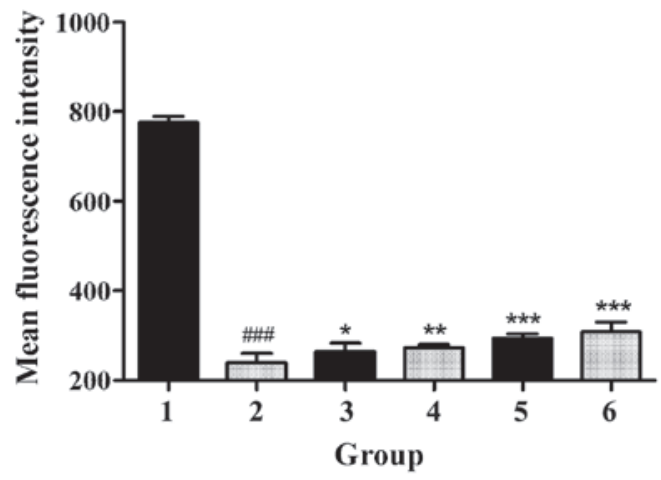

Figure 2. Effect of GBEE on the accumulation and efflux of Rho 123 in S180 MDR cells. (A) The accumulation and (B) efflux of Rho 123 in S180 and S180 MDR cells. Group 1, mean fluorescence intensity of Rho 123 in parent S180 cells; Group 2, mean fluorescence intensity of Rho 123 in S180 MDR cells; Groups 3, 4, 5 and 6, S180 MDR cells treated with GBEE at 7.5, 15 and $30 \mu \mathrm{g} / \mathrm{ml}+$ VER $5 \mu \mathrm{g} / \mathrm{ml}$, respectively; ${ }^{\# \# \#} \mathrm{P}<0.001$ vs. parent cells; ${ }^{*} \mathrm{P}<0.05$, ${ }^{* *} \mathrm{P}<0.01$ and ${ }^{* * *} \mathrm{P}<0.001$ vs. S180 MDR cells. Data are the mean \pm standard deviation of at least three independent experiments performed in triplicate. GBEE, Ginkgo biloba exocarp extracts; Rho 123, Rhodamine 123; VER, verapamil; S180 MDR, mice S180 sarcoma cell line with kinds of chemotherapeutic drugs resistance.

the reported literature, astragalus polysaccharides (32) and Lentinan (33) could are able to reverse MDR in some tumor cell lines in vitro. The total alkaloid concentration from Fritillaria thunbergii (34) has also been shown to be able to enhance the MDR reversal effects of DDP on A549/DDP cells in vitro and in vivo. A clinical observation demonstrated that Brucea Javanica Oil Emulsion (35), which is extracted from Traditional Chinese Medicine plant Brucea Javanica, could enhance the effect of Adramycin on refractory malignant pleural effusion. One of its mechanism may be associated with the reversal effect on patients with primary and secondary drug resistance. The present study observed the effect of GBEE in S180 MDR cells and its ascitic, transplantable solid tumor mouse models, which were established by the simulation of a clinically chemotherapeutic PFC scheme. Experimental results demonstrated that GBEE 7.5, 15 and $30 \mu \mathrm{g} / \mathrm{ml}$ could significantly decrease the $\mathrm{IC}_{50}$ of DDP on S180 MDR cells in vitro and its RIs were 10.16, 11.49 and 8.73 , respectively. In addition, GBEE $12.5,25$ and $50 \mathrm{mg} / \mathrm{kg}$ could effectively reverse the resistance of S180 MDR cells to DDP in vivo and then markedly prolong the survival time and increase the tumor inhibitory rate of mice with GBEE treatment. The results demonstrated that GBEE could reverse the resistance of S180 MDR cells to DDP both in vitro and in vivo. 
A

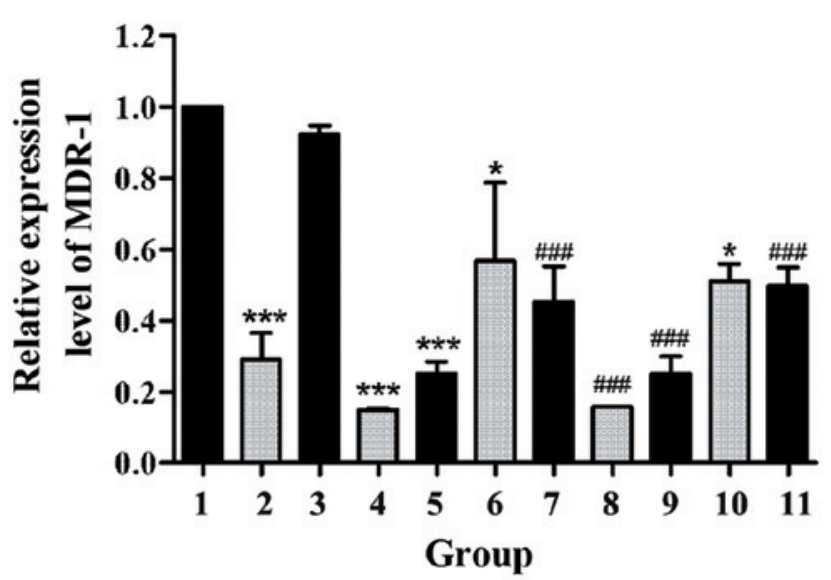

$\mathbf{C}$

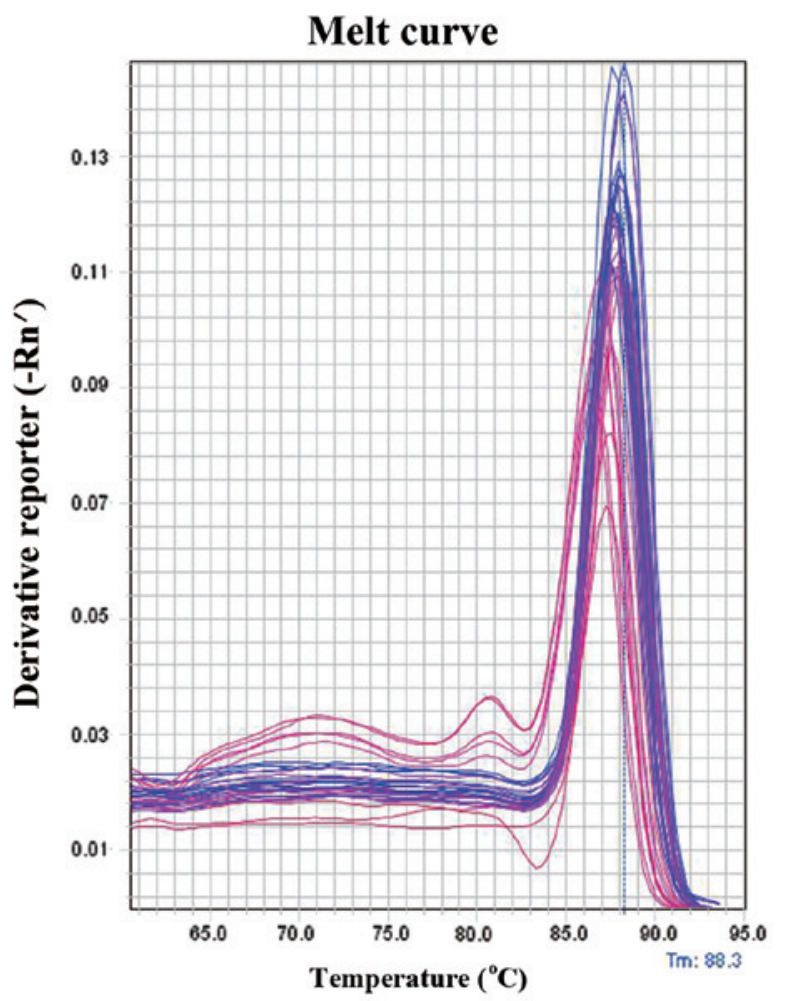

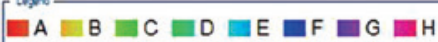

B

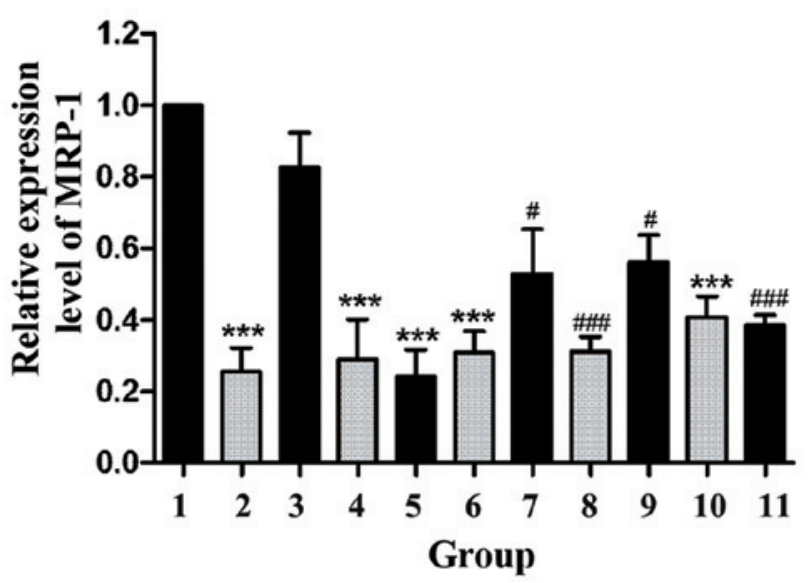

D

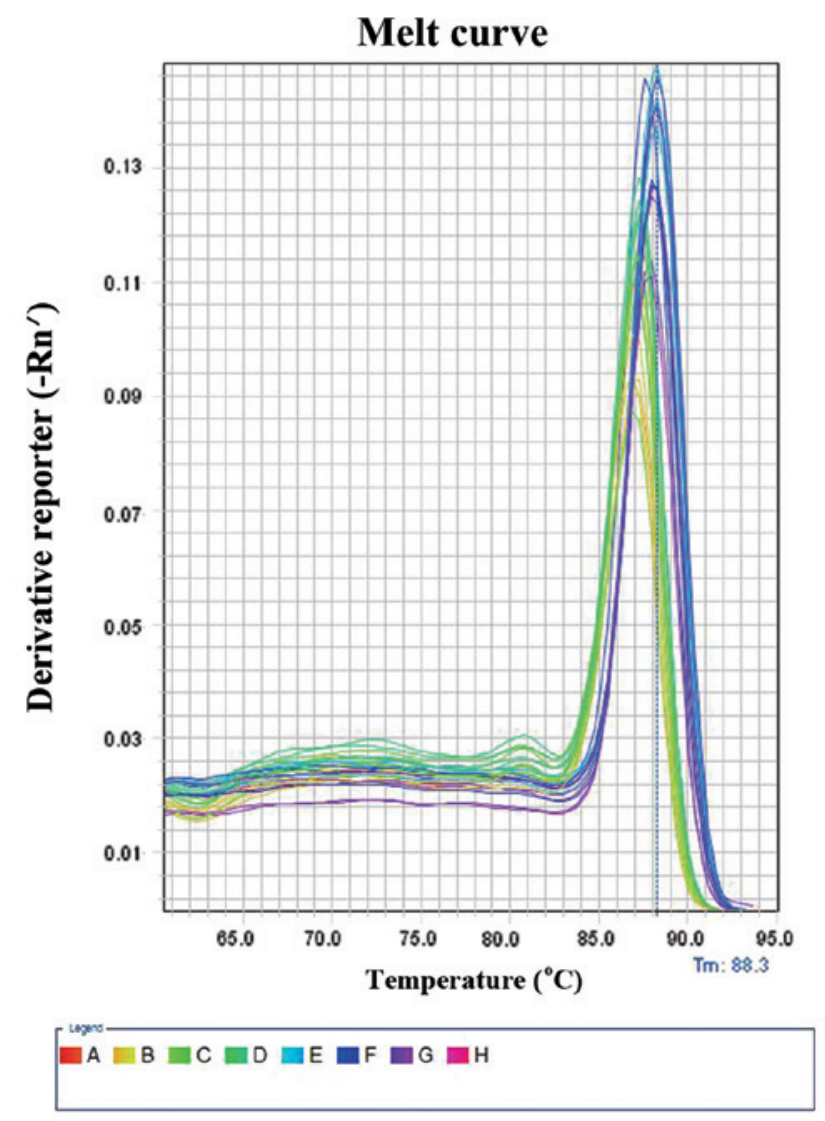

Figure 3. Results of GBEE on the expression of MDR-1 mRNA and MRP-1 mRNA in S180 MDR ascites tumor cells. (A) The MDR-1 mRNA and (B) MRP-1 mRNA expression was analyzed by quantitative polymerase chain reaction. The melting curve of (C) MDR-1 mRNA, (D) MRP-1 mRNA and the GAPDH amplification product in cells of different groups was with a single peak. The data are the mean \pm standard deviation of at least three independent experiments performed in triplicate. Group 1, control group consisting of S180 MDR cells without any treatment; Group 2, blank group consisting of parent S180 cells without any treatment; Group 3, DDP $3.0 \mathrm{mg} / \mathrm{kg}$ was given intraperintoneally every two days, Groups 4, 5, 6, 10, GBEE 12.5, 25 and $50 \mathrm{mg} / \mathrm{kg}+$ VER $15 \mathrm{mg} / \mathrm{kg}$ was given intragastrically once daily. Groups 7, 8, 9, 11, the combination of DDP $3.0 \mathrm{mg} / \mathrm{kg}$ and GBEE $12.5,25,50 \mathrm{mg} / \mathrm{kg}+\mathrm{VER}$ $15 \mathrm{mg} / \mathrm{kg}$. GAPDH was used as an internal control. The mRNA expression levels of MDR1 and MRP1 were quantified by the $2^{-\Delta \Delta C t}$ method and the control group was set as a standard. ${ }^{*} \mathrm{P}<0.05$ and ${ }^{* * * *} \mathrm{P}<0.001$ vs. the control group; ${ }^{\#} \mathrm{P}<0.05$ and ${ }^{\# \# \#} \mathrm{P}<0.001$ vs. the DDP group. GBEE, Ginkgo biloba exocarp extracts; MDR-1, multidrug resistance-1; MRP-1, multidrug resistance-associated protein-1; S180MDR, mice S180 sarcoma cell line with chemotherapeutic drug resistance; VER, verapamil; DDP, cis-dichlorodiamineplatinum.

P-gp, encoded by the MDR-1 gene, is one of the ATP dependent drug efflux pumps (36). MRP is a type of glutathione and glucuronate conjugate pump (37). They were all available to use the energy of ATP to transport the medicine from the intracellular to the extracellular space and as a consequence to weaken the anti-tumor effect. The present study took advantage of the fluorescent properties of ADR (38) and Rho 123 that were used for flow cytometry. The experimental results demonstrated that GBEE 7.5, 15 and $30 \mu \mathrm{g} / \mathrm{ml}$ in vitro could inhibit the functional activity of P-gp on drug-resistant cells. In addition, it could improve the intracellular accumulation of ADR, Rho 123 and induce 
Table III. Inhibition of tumor growth by the combination of GBEE and DDP in a S180 MDR solid tumor mouse model.

\begin{tabular}{lcc}
\hline Group & Tumor mass $(\mathrm{g})$ & Inhibition rate $(\%)$ \\
\hline Blank & & $1.861 \pm 0.81$ \\
Control & & $2.257 \pm 0.32$ \\
DDP & $1.807 \pm 0.50$ & 19.92 \\
GBEE $(\mathrm{mg} / \mathrm{kg})$ & & \\
50 & $1.918 \pm 0.62$ & 15.01 \\
25 & $2.010 \pm 0.46$ & 10.93 \\
12.5 & $1.958 \pm 0.39$ & 13.26 \\
$50+3$ & $1.217 \pm 0.27^{\mathrm{a}}$ & 46.09 \\
GBEE+DDP $(\mathrm{mg} / \mathrm{kg})$ & & \\
$25+3$ & $0.780 \pm 0.18^{\mathrm{a}}$ & 65.43 \\
$12.5+3$ & $0.867 \pm 0.28^{\mathrm{a}}$ & 61.60 \\
VER & $1.867 \pm 0.34$ & 17.29 \\
VER+DDP & $0.886 \pm 0.24^{\mathrm{a}}$ & 60.76 \\
\hline
\end{tabular}

Data are presented as the mean \pm standard deviation for each group of ten mice. The blank group consists of parent S180 cells without any treatment. The control group consists of S180 MDR cells without any treatment. DDP $3 \mathrm{mg} / \mathrm{kg}$ was given intraperitoneally every two days, GBEE 50, 25 and $12.5 \mathrm{mg} / \mathrm{kg}$ and VER $15 \mathrm{mg} / \mathrm{kg}$ were intragastrically given once daily. ${ }^{a} \mathrm{P}<0.001$ vs. DDP; GBEE, Ginkgo biloba exocarp extracts; DDP, cis-dichlorodiamineplatinum; S180 MDR, mice S180 sarcoma cell line with kinds of chemotherapeutic drugs resistance; VER, verapamil.

the efflux of Rho 123. The results of qPCR showed that in vivo GBEE $12.5,25$ and $50 \mathrm{mg} / \mathrm{kg}$ could inhibit the expression of MDR-1 mRNA and MRP-1 mRNA in S180 MDR cells of mice with ascites tumor. Two mRNA expression levels of S180 MDR cells of the GBEE $50 \mathrm{mg} / \mathrm{kg}$ group were 6.711 and 3.455 times lower compared to the control group. Furthermore, the two mRNA expression levels of the GBEE $25 \mathrm{mg} / \mathrm{kg}$ combination group were 5.843 and 2.677 times lower than the DDP $3.0 \mathrm{mg} / \mathrm{kg}$ group. Therefore, it is possible that the reversal mechanism of GBEE is related to the inhibition of the expression of MDR-1 mRNA and MRP-1 mRNA in drug-resistant tumor cells. Furthermore it reduces the composition of the resistant protein and improves the concentration of chemotherapeutic medicine in tumor cells by suppressing the functional activity of P-gp.

A previous study has revealed that MDR-1 itself is a target-antigen (also called 'foreign' element) that can induce $\mathrm{CD}^{+} \mathrm{T}$-cell increase and the secretion of reactive molecules, and promote its lethal effect to MDR tumor cells (39). Promotion of the body's immune function is beneficial to the body in order to identify 'foreign' ABC-resistant proteins and reduce the function of drug-resistant cell pumps that pump out chemotherapeutic drugs by destroying their spatial structure, and then increasing the accumulation of chemotherapeutic drugs in drug-resistant cells to exert an antitumor effect. At the same time, the immune function of the body is beneficial to immune cells that secrete cytokines, some of which can directly or indirectly reverse drug-resistant
A

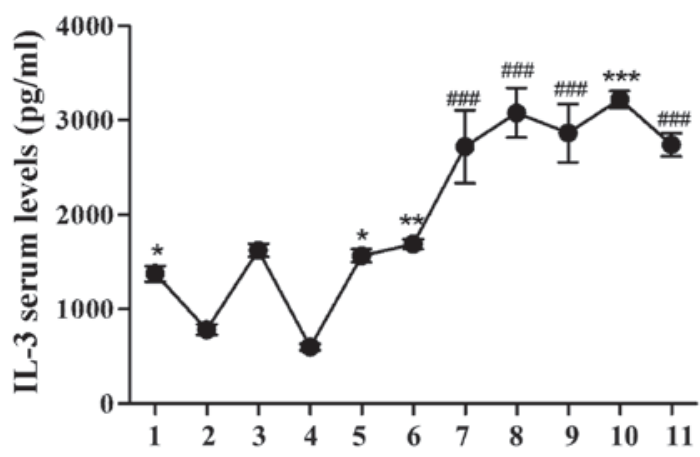

B

Group

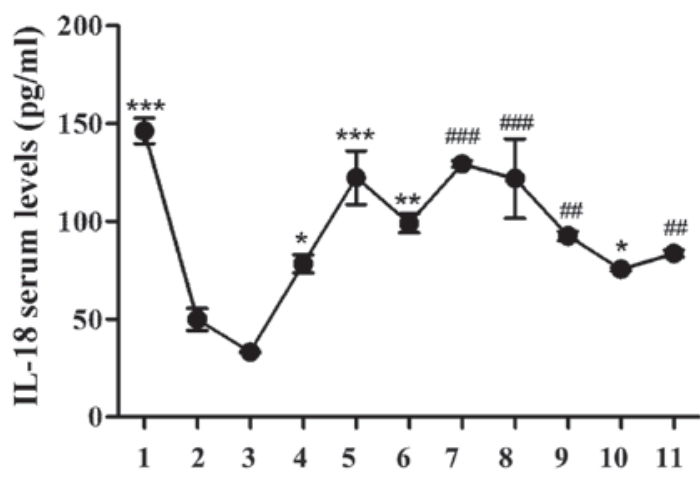

C

Group

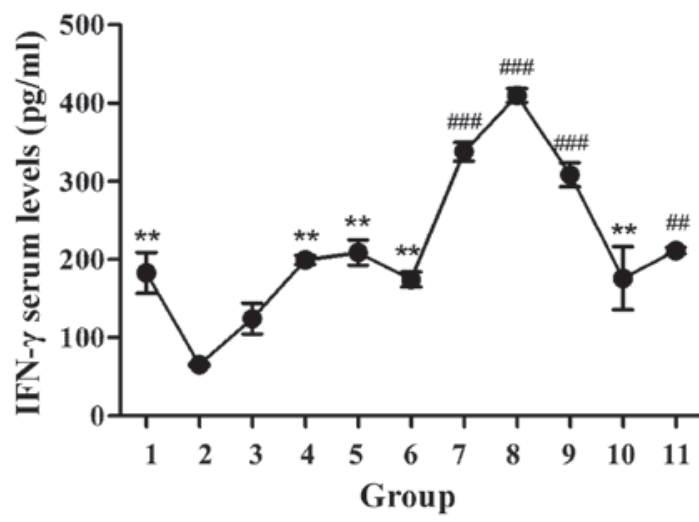

Figure 4. Effect of GBEE on the serum levels of cytokines in S180 MDR tumor-bearing mice. (A) IL-3, (B) IL-18 and (C) IFN- $\gamma$ serum levels of S180 MDR tumor-bearing mice were determined by ELISA. Data are the mean \pm standard deviation of at least three independent experiments performed in triplicate. Group 1, parent S180 cells without any treatment (blank group); Group 2, S180 MDR cells without any treatment (control group). Group 3, DDP $3.0 \mathrm{mg} / \mathrm{kg}$ was given intraperitoneally every two days, Groups 4, 5, 6 and 10, GBEE 12.5, 25, $50 \mathrm{mg} / \mathrm{kg}+$ VER $15 \mathrm{mg} / \mathrm{kg}$ was given intragastrically once daily. Groups 7, 8, 9 and 11, the combination of DDP $3.0 \mathrm{mg} / \mathrm{kg}$ and GBEE $12.5,25,50 \mathrm{mg} / \mathrm{kg}+$ VER $15 \mathrm{mg} / \mathrm{kg} .{ }^{*} \mathrm{P}<0.05,{ }^{* *} \mathrm{P}<0.01$ and ${ }^{* * *} \mathrm{P}<0.001$ vs. control group; ${ }^{\# \#} \mathrm{P}<0.01$ and ${ }^{\# \#} \mathrm{P}<0.001$ vs. DDP group. GBEE, Ginkgo biloba exocarp extracts; S180 MDR, mice S180 sarcoma cell line with chemotherapeutic drug resistance; IL, interleukin; IFN, interferon; DDP, cis-dichlorodiamineplatinum; VER, verapamil.

effects. As an example macrophages and lymphocytes secrete IL-1, IL-2 and IFN- $\gamma$ that can promote ADR and induce the apoptosis of MDR tumor cells by inhibiting the expression of the P-gp protein (40); Cytokine-induced killer 
cells can inhibit the expression of the MDR-1 gene or P-gp, MDR-1, MRP-1 proteins and reverse drug resistance $(41,42)$. Furthermore, IFN- $\alpha$ is produced by mononuclear cells and lymphocytes, which can decrease the expression of resistant proteins, including MRP, P-gp and GST and also reverse drug-resistant effects (43). In addition some of them can also promote the secretion of other cytokines to create a synergy. For example IL-18 can facilitate the secretion of IFN- $\gamma$, IFN- $\alpha$ and IL-2 (44). The majority of patients undergoing chemotherapy have a weakened immune system that is an important cause of MDR. Therefore, the need to find reversal agents that can promote immune function is of great clinical significance. IL-3 produced by T-cells can support the proliferation and differentiation of hematopoietic pluripotent stem and progenitor cells by improving the immune function and promoting hematopoietic function (45). The present study showed that GBEE $12.5,25$ and $50 \mathrm{mg} / \mathrm{kg}$ could significantly increase the serum levels of IL-3, IL-18, IFN- $\gamma$ in S180 MDR tumor-bearing mice $(\mathrm{P}<0.05)$. Furthermore, it improved the immune function, which had a great significance in reversing MDR and enhancing antitumor effects.

To conclude, the present study showed that GBEE could inhibit cell proliferation in the S180 MDR cell line and reverse its drug-resistance in vitro. The results also demonstrated that in vivo GBEE could prolong the survival time of S180 MDR ascites tumor mice and increase the tumor inhibition rate of S180 MDR tumor-bearing mice by inhibiting the expression of MDR-1 mRNA and MRP-1mRNA. Furthemore GBEE could prolong the survival time by increasing the serum levels of IL-3, IL-18 and IFN- $\gamma$, and by influencing the quantity and functional activity of relative drug-resistant proteins. The previous research results showed that GBEE could significantly increase the serum levels of IL-2 and TNF- $\alpha$ in S180 MDR tumor-bearing mice (46). It is also significant to reverse the drug resistance of the tumor. GBEE, therefore, is a promising reversal agent that can be used in the development of treatments for drug-resistant cancer, particularly in combination with other chemotherapeutic drugs.

\section{Acknowledgements}

The present study was supported by the Medical High-Tech Research projects of Jiangsu province (grant no. BG2007609) and the Science and Technology Innovation Fund project for College students in Yangzhou University (grant no. x2014668).

\section{References}

1. Daniel C, Bell C, Burton C, Harguindey S, Reshkin SJ and Rauch C: The role of proton dynamics in the development and maintenance of multidrug resistance in cancer. Biochim Biophys Acta 1832: 606-617, 2013.

2. Huang F, Wu XN, Chen J, Wang WX and Lu ZF: Resveratrol reverses multidrug resistance in human breast cancer doxorubicin-resistant cells. Exp Ther Med 7: 1611-1616, 2014.

3. Molinas A, Sicard G and Jakob I: Functional evidence of multidrug resistance transporters (MDR) in rodent olfactory epithelium. PLoS One 7: e36167, 2012.

4. Wu F, Shao ZY, Zhai BJ, Zhao CL and Shen DM: Ultrasound reverses multidrug resistance in human cancer cells by altering gene expression of $\mathrm{ABC}$ transporter proteins and Bax protein. Ultrasound Med Biol 37: 151-159, 2011.
5. Dean M, Hamon Y and Chimini G: The human ATP-binding cassette (ABC) transporter superfamily. J Lipid Res 42: 1007-1017, 2001

6. Wan X and Sun G: The research progress of immune mechanism of reverse tumor multi-drug resistance. An Hui Yi Yao 10: 401-402, 2006 (In Chinese).

7. Gomes-Giacoia E, Miyake M, Goodison S, Sriharan A, Zhang G, You L, Egan JO, Rhode PR, Parker AS, Chai KX, et al: Intravesical ALT-803 and BCG treatment reduces tumor burden in a carcinogen induced bladder cancer rat model; a role for cytokine production and NK cell expansion. PLoS One 9: e96705, 2014.

8. Johnson SD, De Costa AM and Young MR: Effect of the premalignant and tumor microenvironment on immune cell cytokine production in head and neck cancer. Cancers (Basel) 6: 756-770, 2014.

9. Zhen JH: Progress in research on interleukin -2. Strait Pharmaceutical Journal 18:1-3, 2006.

10. Liu YL, Chen TG and Liu XL: Research progress of interferon. Progress in Veterinary Medicine 29: 81-84, 2008.

11. Fu S and Qian YK: Research progress of tumor necrosis factor. International Journal of Immunology 5: 252-257, 1993.

12. Tu WQ and Yang XQ: Regulation of cytokine immune response and its clinical significance. Foreign Medical Sciences(Section of Pediatrics) 5: 228-232, 1993.

13. Cun YM, Yang YX, Xiang Y,et al: IL-2 gene transfection reversing multidrug resistance in choriocarcinoma cell line. Basic and Clinical Medicine 21: 523-526, 2001.

14. Hu JW, Shen ZY, Yang JC, et al: Combination of interferon gamma and Vera Pammy to reverse multidrug resistance in human lung cancer cell line. Suzhou University Journal of Medical Science 23: 16-18, 2003.

15. Malorni W, Rainaldi G, Tritarelli E, et al: Tumor necrosis factor alpha is a powerful apoptotic inducer in lymphoid leukemic cells expressing the P-170 glycoprotein. International Journal of Cancer 67: 238-47, 1996.

16. Chen X, Fu L and Liu Z: Reversal of multidrug resistance in cancer cell by verapamil: A research progress. Foreign Medical Science (Section of Pharmacy) 34: 190-193, 2007 (In Chinese).

17. Jiao B: Experimental study of reversal of multidrug resistance by cyclosporin a in various human gliom cell lines. Zhong Liu Fang Zhi Yan Jiu 28: 457-459, 2001 (In Chinese).

18. $\mathrm{Xu} \mathrm{AH}$, Chen HS and Zhuo C: The inhibitory effect of Ginkgo biloba endocarp polysaccharides (GBEP) on human cancer cell strains and its synergic effect in combination with adriamycin. Zhong Guo Xin Yao Za Zhi 9: 753-755, 2000 (In Chinese).

19. Chen Y, Mao LL, Hu BY, Chen HS and Xu AH: Synergistic attenuated antitumor effect of Ginkgo biloba exocarp extracts combined with cis-dichlorodiamineplatinum in S180 tumor-bearing mice. Zhong Guo Xin Yao Za Zhi 23: 1569-1573, 2014 (In Chinese).

20. Xu AH, Ren L, Zheng YY and Chen HS: Immunomodulatory effect of Ginkgo biloba exocarp polysaccharides on immunosuppressive mice induced by cyclophosphamide. Zhong Guo Yao Li Xue Yu Du Li Xue Za Zhi 22: 69-72, 2008 (In Chinese).

21. Chen HS, Zhuo F and Chu YF: Clinical study on treatment of patients with upper digestive tract malignant tumors of middle and late stage with Ginkgo biloba exocarp polysaccharides capsule preparation. Zhong Xi Yi Jie He Xue Bao 1: 189-191, 2003 (In Chinese).

22. Zhai F and Chen HS: Ginkgo biloba exocarp Polysaccharide preparation in the treatment of 84 cases of advanced cancer. Liao Ning Zhong Yi Za Zhi 29: 564, 2002.

23. Shen TT, Xu AH, Zheng YY, et al: Anti-metastasis effect of Ginkgo biloba exocarp extracts on metastasis of Lewis lung cancer in C57BL /6J mice and its mechanism. Chin J of Pharmacol Toxicol 27: 67-71, 2013.

24. Xu JL, Wang ZH and FJ S: Establishment of tumor multi-drug resistance mice model induced by combination chemotherapeutic in vivo. Shi Yan Dong Wu Yu Bi Jiao Yi Xue 25: 215-217, 2005.

25. Chen Q, Li GH and Sun FJ: Establishment of obtained multidrug resistance model of S180 cell line mice used for study on Chinese materia medica and its stability. Zhong Cao Yao 37: 1691-1694, 2006 (In Chinese).

26. Wu Q, Xu A, Yang Q, Wang LX and Chen HS: Influence of effective part GBEE-2 of exocarpium ginkgo extracts on apoptosis and apoptotic pathway of human gastric adenocarcinoma cell line SGC-7901. Traditional Chinese Drug Research and Clinical Pharmacology 22: 270-273, 2011. 
27. Cao CJ: Inhibitory effect of extract of Ginkgo biloba extract on liver cancer in mice and its effect on survivin expression. Shi Zhen Guo Yi Guo Yao 26: 1322-1324, 2015.

28. Zrieki A, Farinotti R and Buyse M: Cyclooxygenase-2 inhibitors prevent trinitrobenzene sulfonic acid-induced P-glycoprotein up-regulation in vitro and in vivo. Eur J Pharmacol 636: 189-197, 2010.

29. Loetchutinat C, Saengkhae C, Marbeuf-Gueye C and Garnier-SuillerotA:NewinsightsintotheP-glycoprotein-mediated effluxes of rhodamines. Eur J Biochem 270: 476-485, 2003.

30. Xu SY, Bian RL and Chen X: Screening method of animal tumor in vivo. In:Experimental Methodology of Pharmacology. 3rd (ed.) People's Medical Publishing House, Beijing, pp1757-1784 2002.

31. Isabel D Ferreira 1, Virgílio E do Rosário 1 and Pedro VL Cravo* 2:Real-time quantitative PCR with SYBR Green I detection forestimating copy numbers of nine drug resistance candidate genes in Plasmodium falciparum. Malaria Journal 5: 1-6, 2006.

32. Zhang Y, Jia YJ and Li XJ: Resistance reversal effect of astragalus polysaccharides for injection on cisplatin-resistant human lung adenocarcinoma cell line A549/DDP. Drug Evaluation Research 35: 417-419, 2012 (In Chinese).

33. Wu HY, Chen YM, Lin L, Qiu QA and Liu N: Lentinan enhances cisplatin-mediated inhibition of cell proliferation in human gastric cancer cell line SGC-7901. Shi Jie Hua Ren Xiao Hua Za Zhi 19: 344-348, 2011 (In Chinese)

34. Li ZH, An C, Hu KW, Zhou KH, Duan HH and Tang MK: Multidrug resistance reversal activity of total alkaloid from Fritillaria thunbergii on cisplatin-resistant hum an lung adenocarcinom a A549/DDP cells. Zhong Guo Yao Li Xue Yu Du Li Xue Za Zhi 27: 315-320, 2013 (In Chinese).

35. Zhu C, Liu XF and Li G: Effect of Brucea Javanica oil emulsion combined with adramycin for refractory malignant pleural effusion. Shi Yong Quan Ke Yi Xue 5: 871-873, 2007 (In Chinese).

36. Hennessy M and Spiers JP: A primer on the mechanics of P-glycoprotein the multidrug transporter. Pharmacol Res 55: $1-15,2007$.

37. Kruh GD and Belinsky MG: The MRP family of drug efflux pumps. Oncogene 22: 7537-7552, 2003.
38. Peng YM, Wang N, Wang YF, Han L, Zhang Y, Jiang JH, Zhou YB and Wang QD: Correlation between reversing effect of cepharanthine hydrochloride on multidrug resistance and P-glycoprotein expression and function of K562/ADR cells. Yao Xue Xue Bao 47: 594-599, 2012 (In Chinese).

39. Niethammer AG, Wodrich H, Loeffler M, Lode HN, Emmerich K, Abdollahi A, Krempien R, Debus J, Huber PE and Reisfeld RA: Multidrug resistance-1 (MDR-1): A new target for T cell-based immunotherapy. FASEB J 19: 158-159, 2005.

40. Shi YJ, Ren HY, Cen XN, Zhu Q and Yu JR: Immunological effector cells enhance apoptosis induced by adriamycin in a multi-drug resistant human breast cancer cell line. Zhonghua Zhong Liu Za Zhi 28: 188-191, 2006 (In Chinese).

41. Wang L, Deng Q, Wang J, Bai X, Xiao X, Lv HR, Zhao MF and Liu PJ: Effect of CIK on multidrug-resistance reversal and increasing the sensitivity of ADR in K562/ADR cells. Oncol Lett 8: 1778-1782, 2014.

42. Ping CQ, Zhang YJ, Sun GX, Dong M, Zhou XL, Ping JQm Liu Y and Hong LJ: The expression effect of DC-CIK on K562/A multidrug resistance gene mdr1. Xian Dai Sheng Wu Yi Xue Jin Zhan 14: 2667-2671, 2014 (In Chinese).

43. Wang CH, Pan CX and Wang W: The reversal study of alpha-interferon on human breast cancer multidrug resistance cell lines MX-1/Taxo (MX-1/T). Dang Dai Yi Xue 20: 17-19, 2014 (In Chinese).

44. Li Y, Zou Y, Cai B, Yang B, Ying B, Shi Y and Wang L: The associations of IL-18 serum levels and promoter polymorphism with tacrolimus pharmacokinetics and hepatic allograft dysfunction in Chinese liver transplantation recipients. Gene 491: 251-255, 2012.

45. Yu CF, Hong JH and Chiang CS: The roles of macrophages and nitric oxide in interleukin-3-enhanced HSV-Sr39tk-mediated prodrug therapy. PLoS One 8: e56508, 2013.

46. Li J, Fu EC, Xu AH, et al: Effect of GBEE on the levels of IL-2, IL-12, TNF- and TGF- in tumor bearing mice. Chinese Journal of Immunology 28: 415-417,2012. 